\title{
Ethnomedicines used in Trinidad and Tobago for urinary problems and diabetes mellitus Cheryl A Lans*
}

\author{
Address: BCICS, University of Victoria, British Columbia, V8W 2Y2, Canada \\ Email: Cheryl A Lans* - cher2lans@netscape.net \\ * Corresponding author
}

Published: 13 October 2006

Journal of Ethnobiology and Ethnomedicine 2006, 2:45 doi:10.1186/1746-4269-2-45

This article is available from: http://www.ethnobiomed.com/content/2/1/45

(C) 2006 Lans; licensee BioMed Central Ltd.

This is an Open Access article distributed under the terms of the Creative Commons Attribution License (http://creativecommons.org/licenses/by/2.0), which permits unrestricted use, distribution, and reproduction in any medium, provided the original work is properly cited.
Received: 07 August 2006

Accepted: 13 October 2006

\begin{abstract}
Background: This paper is based on ethnobotanical interviews conducted from 1996-2000 in Trinidad and Tobago with thirty male and female respondents.

Methods: A non-experimental validation was conducted on the plants used for urinary problems and diabetes mellitus: This is a preliminary step to establish that the plants used are safe or effective, to help direct clinical trials, and to inform Caribbean physicians of the plants' known properties to avoid counter-prescribing.
\end{abstract}

Results: The following plants are used to treat diabetes: Antigonon leptopus, Bidens alba, Bidens pilosa, Bixa orellana, Bontia daphnoides, Carica papaya, Catharanthus roseus, Cocos nucifera, Gomphrena globosa, Laportea aestuans, Momordica charantia, Morus alba, Phyllanthus urinaria and Spiranthes acaulis. Apium graviolens is used as a heart tonic and for low blood pressure. Bixa orellana, Bontia daphnoides, Cuscuta americana and Gomphrena globosa are used for jaundice. The following plants are used for hypertension: Aloe vera, Annona muricata, Artocarpus altilis, Bixa orellana, Bidens alba, Bidens pilosa, Bonta daphnoides, Carica papaya, Cecropia peltata, Citrus paradisi, Cola nitida, Crescentia cujete, Gomphrena globosa, Hibiscus sabdariffa, Kalanchoe pinnata, Morus alba, Nopalea cochinellifera, Ocimum campechianum, Passiflora quadrangularis, Persea americana and Tamarindus indicus.

The plants used for kidney problems are Theobroma cacao, Chamaesyce hirta, Flemingia strobilifera, Peperomia rotundifolia, Petiveria alliacea, Nopalea cochinellifera, Apium graveolens, Cynodon dactylon, Eleusine indica, Gomphrena globosa, Pityrogramma calomelanos and Vetiveria zizanioides. Plants are also used for gall stones and for cooling.

Conclusion: Chamaesyce hirta, Cissus verticillata, Kalanchoe pinnata, Peperomia spp., Portulaca oleraceae, Scoparia dulcis, and Zea mays have sufficient evidence to support their traditional use for urinary problems, "cooling" and high cholesterol.

Eggplant extract as a hypocholesterolemic agent has some support but needs more study. The plants used for hypertension, jaundice and diabetes that may be safe and justify more formal evaluation are Annona squamosa, Aloe vera, Apium graveolens, Bidens alba, Carica papaya, Catharanthus roseus, Cecropia peltata, Citrus paradisi, Hibsicus sabdariffa, Momordica charantia, Morus alba, Persea americana, Phyllanthus urinaria, Tamarindus indicus and Tournefortia hirsutissima. Several of the plants are used for more than one condition and further trials should take this into account. 


\section{Background}

Latin American and Caribbean policy makers have recognised that many problems in primary health care are due to lack of knowledge and sensitivity to local health practices, and to the economic and cultural factors associated with these practices [1]. However available herbal products have no clear statement of content; or medically related information on the package labels, and have not been validated or certified by any recognised body. This concerns consumers (potential and actual) and medical practitioners who may unknowingly counter-prescribe these herbal products [1]. Not all of the plants reported to be useful are harmless. These considerations (among others) underlie the study of ethnomedicinal plants used in Trinidad and Tobago from 1995 to 2000 [1]. This paper focuses on the plants used for diabetes, urinary problems and related problems. The World Health Organization has projected that the incidence of type 2 diabetes in Trinidad and Tobago will increase from 70,000 in the year 2000 to 89,000 by the year 2010 [2]. Type 1 diabetes typically affects less than $10 \%$ of patients [3]. Both types of diabetes involve hyperglycemia and several grave complications resulting from long-term hyperglycemia [3]. Control of the glucose levels in the blood is the most effective treatment. Long term reductions in hyperglycemia reduce the likelihood of developing microvascular and macrovascular complications [3]. Type 2 diabetes mellitus has both genetic and environmental components [2]. Previous studies (including Caribbean studies) of offspring or first-degree relatives of patients with type 2 diabetes have confirmed that insulin resistance and/or hyperinsulinaemia is the antecedent biochemical marker for developing diabetes in middle age [2]. First-degree relatives of diabetic patients are more likely to develop diabetes and also have an increased cluster of biochemical metabolic syndrome risk factors [2]. Although insulin resistance is independently associated with obesity, it is more severe in obese patients ( $80 \%$ of type 2 diabetic patients in the West) [3]. Diabetic patients typically have delayed or impaired wound healing, and may develop chronic ulcers [4]. Diabetic ulcers of the lower limbs and feet are associated with high morbidity and amputation is a common treatment. Peripheral neuropathy and peripheral vascular disease are possible underlying factors in diabetic wound formation, but dermal atrophy is a possible contributing factor [4]. Reduced fibroblast growth, increased expression of matrix-degrading matrix metalloproteinases (MMPs), and decreased matrix synthesis are consequences of chronic vascular disease in diabetic skin as well as in other situations characterised by peripheral vascular disease [4]. Atrophic skin is more likely to develop wounds than healthy skin. In addition, insufficient extracellular matrix production during the proliferative phase of wound repair contributes to poor healing [4].
A 1990 Caribbean study on folk medicine used for diabetes mellitus found no difference between non-users of informal medication and those who used it in addition to, or in replacement of, formal medication to control diabetes mellitus in Jamaica [5]. The authors found that teas made from periwinkle (Catharantus species) and rice bitters (Andrographics paniculata) interfered with the control of diabetes mellitus. In a previous study by one of the authors, with more severe cases of diabetes, formal medication gave better control of the diabetes than folk medicine teas [6].

A more recent study conducted in Trinidad and Tobago examined 622 people with diabetes mellitus. Herbal remedies for diabetes were used by 152 (24\%) of patients [7]. Caraaili (Momordica charantia), aloes (Aloe vera), olive bush (Bontia daphnoides) and seed-under-leaf (Phyllanthus urinaria) were the plants most frequently used. Patients who reported burning or numbness in the feet or feelings of tiredness, weakness, giddiness or dizziness used folk medicines more frequently than those who reported other symptoms [7]. Subsequent studies by the same authors have discarded folk medicine and focussed on the standards of conventional medical care for diabetes [8-10]. In a 2004 study they found that diabetes was associated with low income status and worse health status and more frequent expenditure on medical services [9]. Although the authors of this study found that the control group had access to health insurance this access is not common in Trinidad. In an earlier paper the same authors estimated the annual cost of hospital admissions with diabetes at TT10.66 million (UK 1.24 million pounds) [10], type 2 diabetes is a costly and largely avoidable problem.

In the late 1980s an IDRC-funded study examined the prevalence of diabetes and hypertension in women in Trinidad [11]. They screened 4013 women older than 25 years in 3152 households and 769 had been diagnosed with diabetes mellitus or hypertension. They concluded that the women's conditions were not managed adequately by the health system and that they should assume greater responsibility for managing their own health [11]. It is therefore puzzling that little research has been conducted on the medicinal plants used for diabetes and their efficacy.

Instead studies have examined ethnic or gender differences in prevalence of diabetes mellitus or compliance with conventional treatment protocols [12]. Finding alternatives is important because $10-20 \%$ of the population is affected. The leading causes of death and illness for the past thirty years in Trinidad and Tobago have been cardiovascular disease, cerebrovascular disease, cancer, hypertension and diabetes mellitus [13]. In a 2002 study, 2117 randomly selected patients from 35 randomly selected 
government health centres in Trinidad were found to be suffering from diabetes-related foot problems. Of these, $49 \%$ had burning or numbness in the feet, 1241 (59\%) self-reported visual impairment and $12 \%$ had foot ulceration of whom 92 (4\%) had major or minor amputation [14].

This author conducted ethnoveterinary research in Trinidad and Tobago from 1995 to 2000. During this research many ethnomedicinal plant uses were discovered that did not have comparative uses for animals. This paper deals with the twenty-two plants used for hypertension, the four plants used for jaundice and the fourteen used for diabetes. It also presents the forty-five plants for urinary problems, "cooling" and high cholesterol levels.

A substantial body of research published outside the Caribbean since 2000 has provided sufficient data to conduct a preliminary evaluation of the researched plants and this evaluation is presented in the discussion section of this paper [15]. Several (approx. 30) of the plant uses have already been recorded in an ethnomedicinal study in one rural community in the northern range of Trinidad [16] and in the study on diabetes mellitus mentioned previously [7]. Several older studies referred to in the discussion section of the paper were reviewed previously and their original references will not be given for space reasons [1].

\section{The Trinidadian hot/cold system}

Caribbean folk medicine is a marriage- $\alpha$-cinq:European folkmedicine, scientific medicine, African-based practices, Amerindianmedicine and Indian-based medicine, a product of inter-group borrowing or medical syncretism [1]. Activities, food and medicines are classified in various ethnomedicinal systems as hot or cold. The Trinidadian hot/ cold system is not humoral in the sense that balance must be established between hot and cold, it is cathartic in that remedies are taken to remove heat from the system [1]. Some researchers consider that the hot-cold concept of health and illness is absent in Spanish folk medicine and did not exist at the folk level in the past [1]. These beliefs are now widespread in Latin America and the Caribbean, and according to G.M. Foster were derived from the élite and scholarly Hippocratic-galenic traditions that were brought to the Spanish colonies by Spanish physicians and clergy $[17,18]$. The hot-cold valence refers to the traditional belief that heat opens the body and facilitates the blood's free flow, whereas cold causes the blood to stop flowing and clog the arteries, veins and womb $[1,17,18]$. Heat comes from the sun, work, sleeping, burns, cooking, and reproductive activities. Linked to the hot/cold dichotomy is a system of blood beliefs where an excess or lack of cold or heat in the body through exposure or diet causes illness. Blood then becomes 'bad' or dirty [1]. Female
Warao herbalists in Eastern Venezuela also use the concept of bad blood [19].

Teas are used for 'cooling' if there is too much 'heat' in the body. Cooling teas are used prophylatically when they are taken to keep the body healthy by cooling the 'system', or the bladder, meaning that they remove the 'heat' or impurities in the system [1,17-20]. Cooling teas become treatment when they are taken for undiagnosed or unspecified illnesses or when feeling unwell. Purges reduce the heat further and 'clean the blood'. Thereare also 'hot' plants to stimulate the blood or to treat 'cold' illnesses, and 'hot' external applications like 'soft candle' 'grated nutmeg' and hot poultices [1,17-20]. Medicines are administered in accordance with the identity between cause and effect. Expulsion of disease-causing impurities is the primary mechanism by which bodily equilibrium is restored. Folk medicines achieve cures through 'bitterness', 'cutting', 'cooling', 'building', 'purging or washing out', and 'drawing out' [1,17-20].

\section{Methods}

This study adhered to the research guidelines and ethical protocols of Wageningen University in the Netherlands. Thirty respondents, ten of whom were male were interviewed from September 1996 to September 2000. The respondents were obtained by snowball sampling, and were found in thirteen different sites, 12 in Trinidad and one in Tobago. Snowball sampling was used because there was no other means of identifying respondents and because the research covered the entire island-area rather than concentrating on one village. The chief objective of the sampling method was to identify knowledgeable respondents; no priority was given to extrapolating the data to the wider population to establish prevalence of use. No statistical analysis was applied to the data.

Twenty respondents were interviewed once, the other ten (who were healers) were interviewed three or four times. Healers were also asked to reconstruct the circumstances and contexts of the plant uses so that the means of administration of the plants could be identified. No interview schedule of questions was used but a more qualitative, conversational technique. Plants were collected when available to verify that the common names used by each respondent were the same in each ethnic group as those recorded in the literature. The majority of the plants were identified at the Herbarium of the University of the West Indies but voucher samples were not deposited. This ethnomedicinal study was part of a larger research project on ethnoveterinary medicine; other data collecting techniques were used in the larger study [1]. 


\section{Validation of practices}

A preliminary validation of ethnomedicinal practices is considered a preliminary step to establish which plants are safe or effective and which uses should be discontinued. It also ensures that clinical trials are not wasted on plants that are used for cultural or religious reasons. This is important not only because of the waste of time, money and energy, but because negative results can lead to the discrediting of further effort [1].

Anthropologists like Posey [21] and Hastrup and Elsass [22] claim that anthropologists should not decide whether indigenous beliefs and practices are or are not scientific as this has colonial overtones. Other anthropologists claim that indigenous knowledge systems represent the cultural dimension of development and cannot be reduced to the empirical knowledge that they contain [23]. These anthropological reservations have some value; however validation of traditional medicines is important since most scientists will not use local medicines without some form of validation and they have discouraged the use of these medicines leading to their disuse and eventual loss [1]. A framework of indigenous/ethnoveterinary knowledge that can interface with science and technology is more likely to influence scientific research agendas and development work $[1,24]$.

The validation of the remedies was conducted with a nonexperimental method [25]. This method consists of:

1. obtaining an accurate botanical identification,

2. determining whether the folk data can be understood in terms of bioscientific concepts and methods,

3. searching the chemical/pharmaceutical/pharmacological literature for the plant's known chemical constituents and to determine the known physiological effects of either the crude plant, related species, or isolated chemical compounds that the plant is known to contain.

This information is used to assess whether the plant use is based on empirically verifiable principles or whether symbolic aspects of healing are of greater relevance. If ethnobotanical data, phytochemical and pharmacological information supports the folk use of a plant species it can be grouped into the validation level with the highest degree of confidence.

Four levels of validity were established [25]:

1. If no information supports the use it indicates that the plant may be inactive; or no research has been done on the plant.
2. A plant (or closely related species of the same genus), which is used in geographically or temporally distinct areas in the treatment of similar illnesses, attains the lowest level of validity, if no further phytochemical or pharmacological information validates the popular use. Use in other areas increases the likelihood that the plant is active against the illness.

3. If in addition to the ethnobotanical data, phytochemical or pharmacological information also validates the use in Trinidad and Tobago, the plant may exert a physiological action on the patient and is more likely to be effective than those at the lowest level of validity.

4. If ethnobotanical, phytochemical and pharmacological data supports the folk use of the plant, it is grouped in the highest level of validity and is most likely an effective remedy.

\section{Results \\ Plants used for urinary problems}

Forty-five plants were used for urinary problems, "cooling" and high cholesterol levels. The term "stoppage of water" means urinary retention. Four plants were used for bladder problems:Costus scaber, Pilea microphylla, Kalanchoe pinnata and Cocos nucifera. Two plants were used for high cholesterol levels: Solanum melongena and Portulaca oleraceae.Bauhinia cumanensis/Bauhinia excisa and Capraria biflora were used for gall stones.

Twenty-four plants were used for "cooling": Musa species, Begonia humilis, Bontia daphnoides, Cissus verticillata, Coleus aromaticus, Commelina elegans, Cuscuta americana, Cyperus rotundus, Desmodium canum, Entada polystachya, Justicia pectoralis, Momordica charantia, Peperomia pellucida, Ruellia tuberosa, Sansevieria guineensis, Stachytarpheta jamaicensis, Scoparia dulcis, Cassia alata, Capraria biflora, Kalachoe pinnata, Mimosa pudica, Lepianthes peltata, Tournefortia hirsutissima and Solanum americanum.Bauhinia cumanensis, Bauhinia excisa and Capraria biflora were used for gall stones, while Hibiscus sabdariffa was used to "clean the liver and blood".

The following fourteen plants were used for kidney and other urinary problems: Kalachoe pinnata, Mimosa pudica, Chamaesyce hirta, Flemingia strobilifera, Peperomia rotundifolia, Petiveria alliacea, Nopalea cochinellifera, Apium graveolens, Cynodon dactylon, Zea mays, Theobroma cacao, Lepianthes peltata, Eleusine indica, Gomphrena globosa, Pityrogramma calomelanos and Vetiveria zizanioides.

The results are summarized in Table 1. 
Table I: Ethnomedicinal plants used for "cooling", high cholesterol and urinary problems in Trinidad and Tobago

\begin{tabular}{|c|c|c|c|c|}
\hline Scientific name & Family & Common name & Part used & Use \\
\hline Apium graveolens & Apiaceae & Celery & & Kidney tonic \\
\hline Bauhinia cumanensis /excisa & Fabaceae & Monkey step & Bark & Gall stones \\
\hline Begonia humilis & Begoniaceae & Lozeille & & Cooling \\
\hline Bontia daphnoides & Myoporaceae & Olive bush & Leaves & Cooling \\
\hline Capraria biflora & Scrophulariaceae & Du thé pays & Leaves & Gall stones, cooling \\
\hline Cassia alata & Fabaceae & Senna & Leaves & $\begin{array}{l}\text { Cooling with cloves \& } \\
\text { ginger }\end{array}$ \\
\hline Chamaesyce hirta & Euphorbiaceae & Mal nommée & & Kidney problems \\
\hline Cissus verticillata & Vitaceae & Blister bush & Vine & Cooling \\
\hline Cocos nucifera & Arecaceae & Coconut & Root & Bladder stones \\
\hline Coleus aromaticus & Lamiaceae & Spanish thyme & Leaves & Cooling \\
\hline Commelina elegans & Commelinaceae & Water grass & Plant & Cooling \\
\hline Costus scaber & Zingiberaceae & Wild cane & & Cleans bladder \\
\hline Cuscuta americana & Convolvulaceae & Love vine & Vine & Cooling \\
\hline Cynodon dactylon & Poaceae & Dube & & Stoppage of water \\
\hline Cyperus rotundus & Cyperaceae & Nut grass & & Cooling \\
\hline Desmodium canum & Fabaceae & Sweet heart bush & Plant & Cooling \\
\hline Eleusine indica & Poaceae & Dead man's grass & Root, Leaves & Urinary \\
\hline Entada polystachya & Fabaceae & Mayoc chapelle & & Cooling \\
\hline Flemingia strobilifera & Fabaceae & Kidney bush & & Kidney problems \\
\hline Gomphrena globosa & Amaranthaceae & Bachelor button & Leaves & Urinary problems \\
\hline Hibiscus sabdariffa & Malvaceae & Sorrel & Flower \& seed & Cleans liver and blood \\
\hline Justicia pectoralis & Acanthaceae & Carpenter grass & Leaves & Cooling \\
\hline Kalachoe pinnata & Crassulaceae & Wonder of the world & Leaves & Cooling, Bladder stones \\
\hline Lepianthes peltata & Piperaceae & Lani bois & Leaves & Tea \\
\hline Mimosa pudica & Fabaceae & Ti marie, mese marie & & Cooling, Kidney problems \\
\hline Momordica charantia & Cucurbitaceae & Caraaili & Vine & Cooling \\
\hline Musa species & Musaceae & Banana & Dry leaf & Boil for cooling \\
\hline Nopalea cochinellifera & Cactaceae & Rachette & Joint & Kidney stones \\
\hline Peperomia rotundifolia & Piperaceae & Giron fleur, mowon & & Kidney problems \\
\hline Peperomia pellucida & Piperaceae & Shining bush & & Cooling \\
\hline Petiveria alliacea & Phytolaccaceae & Mapourite, kudjuruk & & Kidney problems \\
\hline Pilea microphylla & Urticaceae & Du thé bethelmay & Leaves & Bladder cleanser \\
\hline Pityrogramma calomelanos & Pteridaceae & Fern & & Urinary problems \\
\hline Portulaca oleraceae & Portulacaceae & Pussley & Plant & $\begin{array}{l}\text { Cholesterol, shortness of } \\
\text { breath }\end{array}$ \\
\hline Ruellia tuberosa & Acanthaceae & Minny root & Root & Cooling \\
\hline Sansevieria guineensis & Agavaceae & Langue bouef, lash & Leaves & Cooling \\
\hline Scoparia dulcis & Scrophulariaceae & Sweet broom & Plant & Cooling for babies \\
\hline Solanum americanum & Solanaceae & Agouma, gouma & Plant & Cooling, provides iron \\
\hline Solanum melongena & Solanaceae & Melongene & Fruit & Cholesterol \\
\hline Stachytarpheta jamaicensis & Verbenaceae & Vervine & Leaves & Cooling \\
\hline Theobroma cacao & Sterculiaceae & Cocoa & Core & Eat for urinary problems \\
\hline Tournefortia hirsutissima & Boraginaceae & Chigger bush & Leaves & Cooling \\
\hline Vetiveria zizanioides & Poaceae & Vetivert & & Urinary problems \\
\hline Zea mays & Poaceae & Corn silk & Stigma & Diuretic \\
\hline
\end{tabular}

Plants used for high blood pressure, diabetes and jaundice

Twenty-nine plants are used for diabetes and hypertension including four for jaundice.

Multiple-plant remedies are used for several conditions including one used for jaundice which combined white bachelor button (Gomphrena globosa), olive bush (Bontia daphnoides), small white vere michelle (unidentified), and fine-stemmed rather than thick-stemmed love vine (Cuscuta americana).

The following plants are used to treat diabetes: Antigonon leptopus, Bidens alba, Bidens pilosa, Bontia daphnoides, Carica papaya, Gomphrena globosa, Bixa orellana, Catharanthus roseus, Cocos nucifera, Laportea aestuans, Momordica charantia, Morus alba, Phyllanthus urinaria and Spiranthes acaulis. 
Apium graveolens is used as a heart tonic and the following plants are used for hypertension: Aloe vera, Annona muricata, Artocarpus altilis, Bixa orellana, Bidens alba, Bidens pilosa, Bontia daphnoides, Carica papaya, Cecropia peltata, Citrus paradisi, Cola nitida, Crescentia cujete, Gomphrena globosa, Hibiscus sabdariffa, Kalanchoe pinnata, Nopalea cochinellifera, Morus alba, Ocimum campechianum, Passiflora quadrangularis, Persea americana and Tamarindus indicus. Low blood pressure is treated with Apium graveolens.

Jaundice is treated with the following plants (many of which are also listed above): Bixa orellana, Bontia daphnoides, Gomphrena globosa and Cuscuta americana.

The ethnomedicinal plants used in Trinidad and Tobago for diabetes are summarised in Table 2 .

\section{Discussion}

Non-experimental validation
For each species or genus the ethnomedicinal uses in other countries was examined but will not be presented in the table due to space constraints. Only the most relevant clinical trials are presented. The non-experimental validation is summarised in Tables 3 and 4 . Table 4 is an additional file (see Additional file 1).

\section{Conclusion}

From the 1930s the impact of western medicine in the Caribbean has been that of a dominant paradigm that was not totally accepted, but which offered elements that were selectively appropriated in a process of indigenisation $[117,118]$. The concepts of 'structural superiority' and 'functional strength' imply that western medicine acquired élite status because of its ability to control diseases (or suppress symptoms), while the folk medicinal system retained functional strength because it was more accessible and available to those isolated communities that existed well into the twentieth century $[1,117,118]$. However this explanatory model, western medicine, has become the dominant medical system; the main means of

Table 2: Ethnomedicinal plants used for high blood pressure, jaundice and diabetes in Trinidad and Tobago

\begin{tabular}{|c|c|c|c|c|}
\hline Scientific name & Family & Common name & Plant part used & Use \\
\hline Aloe vera & Liliaceae & Aloes & Leaf gel & Hypertension \\
\hline Annona muricata & Annonaceae & Soursop & Leaves & Hypertension \\
\hline Antigonon leptopus & Polygonaceae & Coralita & Vine & Diabetes \\
\hline Apium graveolens & Apiaceae & Celery & & $\begin{array}{l}\text { Heart tonic, Low blood } \\
\text { pressure }\end{array}$ \\
\hline Artocarpus altilis & Moraceae & Breadfruit & Leaves & Hypertension \\
\hline Bidens alba/Bidens pilosa & Asteraceae & Needle grass & Leafy branch & Hypertension, Diabetes \\
\hline Bixa orellana & Bixaceae & Roucou & Leaves, root & $\begin{array}{l}\text { Hypertension, Diabetes, } \\
\text { Jaundice }\end{array}$ \\
\hline Bontia daphnoides & Myoporaceae & Olive bush & Leaves & $\begin{array}{l}\text { Diabetes, Jaundice, } \\
\text { Hypertension }\end{array}$ \\
\hline Carica papaya & Caricaceae & Papaya & Green fruit & Hypertension, Diabetes \\
\hline Catharanthus roseus & Apocynaceae & White Periwinkle & & Diabetes \\
\hline Cecropia peltata & Cecropiaceae & Bois canôt & Leaves & Hypertension \\
\hline Citrus paradisi & Rutaceae & Grapefruit & Peel & Hypertension \\
\hline Cocos nucifera & Arecaceae & Coconut & Shell, flower & Diabetes \\
\hline Cola nitida & Sterculiaceae & Obie seed & Seed & Hypertension \\
\hline Crescentia cujete & Bignoniaceae & Calabash & Leaves & Hypertension \\
\hline Cuscuta americana & Convolvulaceae & Love vine & Vine & Jaundice \\
\hline Gomphrena globosa & Amaranthaceae & Bachelor button & Leaves & $\begin{array}{l}\text { Jaundice, Diabetes, } \\
\text { Hypertension }\end{array}$ \\
\hline Hibiscus sabdariffa & Malvaceae & Sorrel & Leaf & Hypertension \\
\hline Kalanchoe pinnata & Crassulaceae & W/world & Leaf & Hypertension \\
\hline Laportea aestuans & Urticaceae & Red stinging nettle & Leaves & Diabetes \\
\hline Momordica charantia & Cucurbitaceae & Caraaili & & Diabetes \\
\hline Morus alba & Moraceae & Pawi bush & & Diabetes, Hypertension \\
\hline Nopalea cochinellifera & Cactaceae & Rachette & Joint & Hypertension \\
\hline Ocimum campechianum & Lamiaceae & Ti bom & Leaves & Hypertension \\
\hline Passiflora quadrangularis & Passifloraceae & Barbadine & Leaves & Hypertension \\
\hline Persea americana & Lauraceae & Avocado & Leaf & Hypertension \\
\hline Phyllanthus urinaria & Euphorbiaceae & Red seed under leaf & & Diabetes \\
\hline Spiranthes acaulis & Orchidaceae & Lapsogen & & Early-stage diabetes \\
\hline Tamarindus indicus & Fabaceae & Tamarind & Seed & Hypertension \\
\hline
\end{tabular}


Table 3: Validation of plants used for "cooling", high cholesterol and urinary problems in Trinidad and Tobago

\begin{tabular}{|c|c|c|c|}
\hline Scientific name & Common name & Use & Validation score \\
\hline Apium graveolens & Celery & Kidney tonic & 3 for pain \\
\hline Bauhinia cumanensis /excisa & Monkey step & Gall stones & 3 for pain \\
\hline Begonia humilis & Lozeille & Cooling & 2 \\
\hline Bontia daphnoides & Olive bush & Cooling & 2 \\
\hline Capraria biflora & Du thé pays & Gall stones, cooling & 3 for pain \\
\hline Cassia alata & Senna & Cooling with cloves and ginger & 2 \\
\hline Chamaesyce hirta & Malomay, Mal nommée & Kidney problems & 3 diuretic; 3 sedative \\
\hline Cissus verticillata & Blister bush & Cooling & 3 diarrhoea; 3 gastric ulcers \\
\hline Cocos nucifera & Coconut & Bladder stones & 2 \\
\hline Coleus aromaticus & Spanish thyme & Cooling & 2 \\
\hline Commelina elegans & Water grass & Cooling & 2 \\
\hline Costus scaber & Wild cane & Cleans bladder & data needed \\
\hline Cuscuta americana & Love vine & Cooling & 2 \\
\hline Cynodon dactylon & Dube & Stoppage of water & 2 \\
\hline Cyperus rotundus & Nut grass & Cooling & 3 \\
\hline Desmodium canum & Sweet heart bush & Cooling & 3 \\
\hline Eleusine indica & Dead man's grass & Urinary & 2 \\
\hline Entada polystachya & Mayoc chapelle & Cooling & 2 data needed \\
\hline Flemingia strobilifera & Kidney bush & Kidney problems & 2 data needed \\
\hline Gomphrena globosa & Bachelor button & Urinary problems & 2 data needed \\
\hline Hibiscus sabdariffa & Sorrel & Cleans liver and blood & 3 hypertension; 3 liver problems \\
\hline Justicia pectoralis & Carpenter grass & Cooling & Data needed \\
\hline Kalachoe pinnata & Wonder of the world & Cooling, Bladder stones & 3 jaundice \\
\hline Lepianthes peltata & Lani bois & Tea & Data needed \\
\hline Mimosa pudica & Ti marie, mese marie & Cooling, Kidney problems & 2 \\
\hline Momordica charantia & Caraaili & Cooling & Data needed \\
\hline Musa species & Banana & Boil for cooling & 2 \\
\hline Nopalea cochinellifera & Rachette & Kidney stones & 2 data needed \\
\hline Peperomia rotundifolia & Giron fleur, mowon & Kidney problems & 3 \\
\hline Peperomia pellucida & Shining bush & Cooling & 3 \\
\hline Petiveria alliacea & Mapourite, kudjuruk & Kidney problems & Data needed \\
\hline Pilea microphylla & Du thé bethelmay & Bladder cleanser & 2 \\
\hline Pityrogramma calomelanos & Fern & Urinary problems & Data needed \\
\hline Portulaca oleraceae & Pussley & Cholesterol, short breath & 3 pain; 3 gastroprotective \\
\hline Ruellia tuberosa & Minny root & Cooling & Data needed \\
\hline Sansevieria guineensis & Langue bouef, lash & Cooling & Data needed \\
\hline Scoparia dulcis & Sweet broom & Cooling for babies & 3 pain; 3 diuretic \\
\hline Solanum americanum & Agouma, gouma & Cooling, provides iron & 2 data needed \\
\hline Solanum melongena & Melongene & Cholesterol & Not proven \\
\hline Stachytarpheta jamaicensis & Vervine & Cooling & Data needed \\
\hline Theobroma cacao & Cocoa & Eat for urinary problems & Data needed \\
\hline Vetiveria zizanioides & Vetivert & Urinary problems & Data needed \\
\hline Zea mays & Corn silk & Diuretic & 3 diuretic \\
\hline
\end{tabular}

establishing whether a technology works and how. The non-experimental validation of the ethnoveterinary medicines was undertaken in recognition of that fact. Validation of traditional medicines is important since most scientists will not use local medicines without some form of validation and they have discouraged the use of these medicines leading to their disuse and eventual loss [1]. This loss is exacerbated by the death of knowledgeable elders. A framework of indigenous knowledge that can interface with science and technology is more likely to influence scientific research agendas and development work, leading to the integration of indigenous knowledge into modern life $[1,24]$.

More data is necessary to evaluate the safety of the following plants used to treat urinary problems, "cooling" and high cholesterol levels: Costus scaber, Cynodon dactylon, Entada polystachya, Flemingia strobilifera, Gomprena globosa, Justicia pectoralis, Lepianthes pelata, Momordica charantia, Nopalea cochenillifera, Petiveria alliacea, Pityrogramma 
calomelanos, Ruellia tuberosa, Sansevieriea guineensis, Stachytarpheta jamaicensis, Theobroma cacao and Vetiveria zizanioides.

Little data was found to support the use of the following plants to treat urinary problems: Justicia pectoralis, Lepianthes pelata, Momordica charantia, Petiveria alliacea, Pityrogramma calomelanos, Ruellia tuberosa, Sansevieriea guineensis, Stachytarpheta jamaicensis, Theobroma cacao and Vetiveria zizanioides.

The following plants have established analgesic or sedative effects: Apium graveolens, Bauhinia cumanensis, Capraria biflora, Chamaesyce hirta and Portulaca oleraceae.

Chamaesyce hirta, Cissus verticillata, Kalanchoe pinnata, Peperomia spp.,

Chamaesyce hirta, Cissus verticillata, Kalanchoe pinnata, Peperomia spp., Portulaca oleraceae, Scoparia dulcis, and Zea mays have sufficient evidence to support their traditional use for urinary problems, "cooling" and high cholesterol. Cuscuta americana also merits more study.

The plants used for hypertension, jaundice and diabetes that may be safe and justify more formal evaluation are Annona squamosa, Aloe vera, Apium graveolens, Bidens alba, Carica papaya, Catharanthus roseus, Cecropia peltata, Citrus paradisi, Hibsicus sabdariffa, Momordica charantia, Morus alba, Persea americana, Phyllanthus urinaria, Tamarindus indicus and Tournefortia hirsutissima. Several of the plants are used for more than one condition and further trials should take this into account. The use of eggplant extract as a hypocholesterolemic agent has some support but needs more study.

It is likely that medical practitioners in Trinidad and Tobago are counter-prescribing the majority of these remedies and should learn more about them.

\section{Competing interests}

The author(s) declare that they have no competing interests.

\section{Additional material}

\section{Additional File 1}

Table 4. Non-experimental validation of plants used in Trinidad and Tobago for diabetes and urinary problems. The data provided represents the chemical/pharmaceutical/pharmacological literature of the plant's known chemical constituents to determine the known physiological effects of either the crude plant, related species, or isolated chemical compounds that the plant is known to contain, and also any relevant clinical trials. Click here for file

[http://www.biomedcentral.com/content/supplementary/1746-

4269-2-45-S1.pdf]

\section{Acknowledgements}

This data collection was part of a larger study for a Ph.D. at Wageningen UR, the Netherlands. The fellowship support provided is appreciated. The Herbarium staff of the University of the West Indies provided essential plant identification. Dr. Lionel Robineau helped with the database searches. Dr. A.J.J. van den Berg provided invaluable editorial and pharmacological help.

\section{References}

I. Lans C: Creole remedies of Trinidad and Tobago book self-published on Lulu.com; 2006.

2. Ezenwaka CE, Kalloo R, Uhlig M, Eckel J: Relationship between adiponectin and metabolic variables in Caribbean offspring of patients with type 2 diabetes mellitus. Horm Metab Res 2004, 36(4):238-42.

3. Attele AS, Zhou YP, Xie JT, Wu JA, Zhang L, Dey L, Pugh W, Rue PA, Polonsky KS, Yuan CS: Antidiabetic effects of Panax ginseng berry extract and the identification of an effective component. Diabetes 2002, 5 I(6): | 85 I-8.

4. Lateef H, Abatan OI, Aslam MN, Stevens MJ, Varani J: Topical pretreatment of diabetic rats with all-trans retinoic acid improves healing of subsequently induced abrasion wounds. Diabetes 2005, 54(3):855-6I

5. Alleyne S, Cruickshank JK: The use of informal medication - particularly bush teas - in Jamaican patients with diabetes mellitus. Cajanus 1990, 23(I):57-67.

6. Alleyne SI, Morrison EY, St A, Richard RR: Some social factors related to control of diabetes mellitus in adult Jamaican patients. Diabetes Care 1979, 2:40 I-408.

7. Mahabir D, Gulliford MC: Use of medicinal plants for diabetes in Trinidad and Tobago. Revista Panamericana de Salud Pública 1997, I(3): $174-179$

8. Mahabir D, Gulliford MC: Changing patterns of primary care for diabetes in Trinidad and Tobago over 10 years. Diabet Med 2005, 22(5):619-24.

9. Gulliford MC, Mahabir D, Rocke B: Diabetes-related inequalities in health status and financial barriers to health care access in a population-based study. Diabet Med 2004, 2 I (I):45-5I.

10. Gulliford MC, Ariyanayagam-Baksh SM, Bickram L, Picou D, Mahabir $\mathrm{D}$ : Counting the cost of diabetic hospital admissions from a multi-ethnic population in Trinidad. Diabet Med 1995, I 2(1 2): 1077-85.

II. Zarowsky C, Stansfield S: Diabetes and hypertension in women (Trinidad) IDRC, Ottawa, Canada.

12. Babwah F, Baksh S, Blake L, Cupid-Thuesday J, Hosein I, Sookhai A, Poon-King $C$, Hutchinson G: The role of gender in compliance and attendance at an outpatient clinic for type 2 diabetes mellitus in Trinidad. Rev Panam Salud Publica 2006, I 9(2):79-84.

13. Carr B-A, Alleyne L, Renaud D: Report on the results of the Global Youth Tobacco survey in Trindad and Tobago - 2000. [http://www.cdc.gov/tobacco/Global/gyts/reports/paho/2000/ Trinidad and Tobago 2000 Paho0l.htm]. National Center for Chronic Disease Prevention and Health Promotion. PAHO. WHO Canadian Public Health Association 
14. Gulliford MC, Mahabir D: Diabetic foot disease and foot care in a Caribbean community. Diabetes Res Clin Pract 2002, 56(I):35-40.

15. Grover JK, Yadav S, Vats V: Medicinal plants of India with antidiabetic potential. J Ethnopharmacol 2002, 8I (I):8I-I00.

16. Wong W: Some folk medicinal plants from Trinidad. Economic Botany 1976, 30:103-|42.

17. Foster GM: Relationships between Spanish and SpanishAmerican folk medicine. Journal of American Folklore 1953, 66:201-217

18. Aho WR, Minott K: Creole and doctor medicine: folk beliefs, practices, and orientations to modern medicine in a rural and an industrial suburban setting in Trinidad and Tobago, the West Indies. Social Science and Medicine 1977, I I (5):349-355.

19. Wilbert W: The Pneumatic theory of female Warao herbalists. Social Science and Medicine 1983, 25( I 0): I I39- I I 46.

20. Littlewood R: From vice to madness: the semantics of naturalistic and personalistic understandings in Trinidadian local medicine. Social Science and Medicine 1988, 27(2): | 29- | 48.

21. Posey DA: Changing fortunes: biodiversity and peasant livelihood in the Peruvian Andes. Journal of Latin American Studies 1998, 30(3):682-683.

22. Hastrup K, Elsass P: Anthropological advocacy. Current Anthropology 1990, 3 I(3):30I-3II.

23. Warren DM, Slikkerveer LJ, Brokensha DW, Eds: The cultural dimension of development: Indigenous knowledge systems Intermediate Technology Publications, London; 1995.

24. Sillitoe P: The development of indigenous knowledge. Current Anthropology 1998, 39(2):223-252.

25. Heinrich N, Rimpler H, Antonio-Barrerra N: Indigenous phytotherapy of gastrointestinal disorders in a lowland Mixe community (Oaxaca, Mexico): ethnopharmacological evaluation. J Ethnopharmacol 1992, 36(I):63-80.

26. Chithra P, Sajithlal GB, Chanrakasan G: Influence of Aloe vera on the glycosaminoglycans in the matrix of healing dermal wounds in rats. Journal of Ethnopharmacology 1998, 59(3): I79-186.

27. Shirwaikar A, Rajendran K, Dinesh Kumar C, Bodla R: Antidiabetic activity of aqueous leaf extract of Annona squamosa in streptozotocin-nicotinamide type 2 diabetic rats. J Ethnopharmacol 2004, $91($ I): $|7|-5$.

28. Chistokhodova N, Nguyen C, Calvino T, Kachirskaia I, Cunningham G, Howard Miles D: Antithrombin activity of medicinal plants from central Florida. J Ethnopharmacol 2002, 8 I (2):277-80.

29. Atta $\mathrm{AH}$, Alkofahi $\mathrm{A}$ : Anti-nociceptive and anti-inflammatory effects of some Jordanian medicinal plant extracts. I Ethnopharmacol 1998, 60(2): I I7-124.

30. Yadava RN, Reddy VM: Anti-inflammatory activity of a novel flavonol glycoside from the Bauhinia variegata Linn. Nat Prod Res 2003, I 7(3): I65-9.

31. Meyre-Silva C, Yunes RA, Delle Monache F, Santos AR, Schmeling LO, Gadotti VM, Liz F, Cechinel-Filho V: Phytochemical and pharmacological analysis of Bauhinia microstachya (Raddi) Macbr. (Leguminosae). Z Naturforsch [C] 200 I, 56(I I-I 2):939-42.

32. Ramesh N, Viswanathan MB, Saraswathy A, Balakrishna K, Brindha P, Lakshmanaperumalsamy P: Phytochemical and antimicrobial studies of Begonia malabarica. I Ethnopharmacol 1998, 79(I): 129-132.

33. Chang SL, Chang CL, Chiang YM, Hsieh RH, Tzeng CR, Wu TK, Sytwu HK, Shyur LF, Yang WC: Polyacetylenic compounds and butanol fraction from Bidens pilosa can modulate the differentiation of helper $T$ cells and prevent autoimmune diabetes in non-obese diabetic mice. Planta Med 2004, 70 (I I): 1045-5 I.

34. Russell KR, Morrison EY, Ragoobirsingh D: The effect of annatto on insulin binding properties in the dog. Phytother Res 2005, I 9(5):433-6

35. De-Oliveira AC, Silva IB, Manhaes-Rocha DA, Paumgartten FJ: Induction of liver monooxygenases by annatto and bixin in female rats. Braz J Med Biol Res 2003, 36(I): I I3-8.

36. Liogier HA: Plantas medicinales de Puerto Rico y del Caribe Iberoamericana de Ediciones, Inc., San Juan, PR; 1990:566.

37. Kelcher S, West J, Crisp M, Chinnock R: The Caribbean Bontia daphnoides and its Australian family Myoporaceae (Lamiales): evidence of an extreme dispersal event from morphological data and rpllo intron sequences. [http://
[ www.botany200l.org/sympos /2/abstracts/4.shtml].
38. von Reis S, Lipp FJ: New Plant Sources for Drugs and Foods from The New York Botanical Garden Herbarium Cambridge, MA: Harvard University Press; 1982.

39. Acosta SL, Muro LV, Sacerio AL, Pena AR, Okwei SN: Analgesic properties of Capraria biflora leaves aqueous extract. Fitoterapia 2003, 74(7-8):686-8.

40. Collins DO, Gallimore WA, Reynolds WF, Williams LA, Reese PB: New skeletal sesquiterpenoids, caprariolides $A-D$, from Capraria biflora and their insecticidal activity. J Nat Prod 2000, 63(I I): $1515-1518$

41. Savickiene N, Dagilyte A, Lukosius A, Zitkevicius V: Importance of biologically active components and plants in the prevention of complications of diabetes mellitus. Medicina (Kaunas) 2002, 38( I 0):970-5. Article in Lithuanian

42. Eno $\mathrm{AE}$, Owo OI, Itam $\mathrm{EH}$, Konya RS: Blood pressure depression by the fruit juice of Carica papaya (L.) in renal and DOCAinduced hypertension in the rat. Phytother Res 2000 , I4(4):235-9.

43. Palanichamy S, Nagarajan S, Devasagayam M: Effect of Cassia alata leaf extract on hyperglycemic rats. J Ethnopharmacol 1988, 22(I):81-90.

44. Nammi S, Boini MK, Lodagala SD, Behara RB: The juice of fresh leaves of Catharanthus roseus Linn. reduces blood glucose in normal and alloxan diabetic rabbits. BMC Complement Altern Med 2003, 3(I):4.

45. Perez-Guerrero C, Herrera MD, Ortiz R, Alvarez de Sotomayor M, Fernandez MA: A pharmacological study of Cecropia obtusifolia Bertol aqueous extract. J Ethnopharmacol 200I, 76(3):279-84.

46. Rocha FF, Lapa AJ, De Lima TC: Evaluation of the anxiolytic-like effects of Cecropia glazioui Sneth in mice. Pharmacol Biochem Behav 2002, 7 I (I-2): I83-90.

47. Johnson PB, Abdurahman EM, Tiam EA, Abdu-Aguye I, Hussaini IM: Euphorbia hirta leaf extracts increase urine output and electrolytes in rats. I Ethnopharmacol 1999, 65(1):63-9.

48. Lanhers MC, Fleurentin J, Dorfman P, Mortier F, Pelt JM: Analgesic, antipyretic and anti-inflammatory properties of Euphorbia hirta. Planta Med I99I, 57(3):225-3I.

49. García MD, Saenz MT, Puerta R, Quilez A, Fernandez MA: Antibacterial activity of Agave intermixta and Cissus sicyoides. Fitoterapia 1999, 70(I):7I-73.

50. Jainu M, Devi CS: Effect of Cissus quadrangularis on gastric mucosal defensive factors in experimentally induced gastric ulcer-a comparative study with sucralfate. J Med Food 2004 7(3):372-6.

51. Longanga Otshudi AL, Vercruysse A, Foriers A: Contribution to the ethnobotanical, phytochemical and pharmacological studies of traditionally used medicinal plants in the treatment of dysentery and diarrhoea in Lomela area, Democratic Republic of Congo (DRC). J Ethnopharmacol 2000, 7 I (3): 4 I I-423.

52. Gorinstein S, Caspi A, Libman I, Katrich E, Lerner HT, Trakhtenberg $\mathrm{S}$ : Fresh israeli jaffa sweetie juice consumption improves lipid metabolism and increases antioxidant capacity in hypercholesterolemic patients suffering from coronary artery disease: studies in vitro and in humans and positive changes in albumin and fibrinogen fractions. I Agric Food Chem 2004, 52( 1 6):5215-22.

53. Kirszberg C, Esquenazi D, Alviano CS, Rumjanek VM: The effect of a catechin-rich extract of Cocos nucifera on lymphocytes proliferation. Phytother Res 2003, I 7(9): 1054-8.

54. Alanis AD, Calzada F, Cervantes JA, Torres J, Ceballos GM: Antibacterial properties of some plants used in Mexican traditional medicine for the treatment of gastrointestinal disorders. J Ethnopharmacol 2005, I00(I-2): 153-7.

55. Alleyne T, Roache S, Thomas C, Shirley A: The control of hypertension by use of coconut water and mauby: two tropical food drinks. West Indian Med J 2005, 54(I):3-8.

56. Kumaran A, Joel karunakaran R: Antioxidant and free radical scavenging activity of an aqueous extract of Coleus aromaticus. Food Chemistry 2006, 97(I): I09-II4.

57. Youn JY, Park HY, Cho KH: Anti-hyperglycemic activity of Commelina communis L.: inhibition of alpha-glucosidase. Diabetes Res Clin Pract 2004, 66(Suppl I):SI 49-55.

58. Kala Prakash Chandra, Farooquee Dhar Nehal A, Uppeandra : Prioritization of medicinal plants on the basis of available knowl- 
edge, existing practices and use value status in Uttaranchal, India. Biodiversity and Conservation 2004, 13(2):453-469.

59. Mazumder UK, Gupta M, Pal D, Bhattacharya S: Chemical and toxicological evaluation of methanol extract of Cuscuta reflexa Roxb. stem and Corchorus olitorius Linn. seed on hematological parameters and hepatorenal functions in mice. Acta Pol Pharm 2003, 60(4):317-23.

60. Gupta M, Mazumder UK, Pal DK, Bhattacharya S: Onset of puberty and ovarian steroidogenesis following adminstration of methanolic extract of Cuscuta reflexa Roxb. stem and Corchorus olitorius Linn. seed in mice. Journal of Ethnopharmacology 2003, 89(I):55-59.

6I. Pal D, Panda C, Sinhababu S, Dutta A, Bhattacharya S: Evaluation of psychopharmacological effects of petroleum ether extract of Cuscuta reflexa Roxb. stem in mice. Acta Pol Pharm 2003, 60(6):48I-6.

62. Shinwari MI, Khan MA: Folk use of medicinal herbs of Margalla Hills National Park, Islamabad. J Ethnopharmacol 2000, 69(1):45-56

63. Roman Ramos R, Alarcon-Aguilar F, Lara-Lemus A, Flores-Saenz JL: Hypoglycemic effect of plants used in Mexico as antidiabetics. Arch Med Res 1992, 23(I):59-64.

64. Auddy B, Ferreira M, Blasina F, Lafon L, Arredondo F, Dajas F, Tripathi PC, Seal T, Mukherjee B: Screening of antioxidant activity of three Indian medicinal plants, traditionally used for the management of neurodegenerative diseases. I Ethnopharmacol 2003, 84(2-3): | $31-138$.

65. Jagtap AG, Shirke SS, Phadke AS: Effect of polyherbal formulation on experimental models of inflammatory bowel diseases. J Ethnopharmacol 2004, 90(2-3): 195-204.

66. Rao M, Rao MNA: Protective effects of cystone, a polyherbal ayurvedic preparation, on cisplatin-induced renal toxicity in rats. J Ethnopharmacol 1998, 62(I): I-6.

67. Barreto GS: Effect of butanolic fraction of Desmodium adscendens on the anococcygeus of the rat. Braz J Biol 2002, 62(2):223-30.

68. Sugimoto K, Sakurai N, Shirasawa H, Fujise Y, Shibata K, Shimodo K, Sakata J: Bovine cases of urolithiasis treated with traditional herbal medicine, P-3. J Vet Med Sci 1992, 54(3):579-582.

69. Monache GD, Botta B, Vinciguerra V, de Mello JF, Andrade Chiapetta de $A$ : Antimicrobial isoflavanones from Desmodium canum. Phytochemistry 1996, 4 I (2):537-544.

70. Nyarko AK, Asare-Anane $\mathrm{H}$, Ofosuhene M, Addy ME: Extract of Ocimum canum lowers blood glucose and facilitates insulin release by isolated pancreatic beta-islet cells. Phytomedicine 2002, 9(4):346-5।.

71. Ho CS, Wong YH, Chiu KW: The hypotensive action of Desmodium styracifolium and Clematis chinensis. Am J Chin Med 1989, I7(3-4): 189-202.

72. Lakshmi Kumari P, Sumathi S: Effect of consumption of finger millet on hyperglycemia in non-insulin dependent diabetes mellitus (NIDDM) subjects. Plant Foods Hum Nutr 2002, 57(34):205-I3.

73. Cos P, Hermans N, De Bruyne T, Apers S, Sindambiwe JB, Vanden Berghe D, Pieters L, Vlietinck AJ: Further evaluation of Rwandan medicinal plant extracts for their antimicrobial and antiviral activities. J Ethnopharmacol 2002, 79(2): I55-63.

74. Fabry W, Okemo $P$, Ansorg R: Fungistatic and fungicidal activity of east African medicinal plants. Mycoses 1996, 39(I-2):67-70.

75. Akinsinde KA, Olukoya DK: Vibriocidal activities of some local herbs. J Diarrhoeal Dis Res 1995, I3(2): 127-9.

76. Rahman MM, Sarker SD, Byres M, Gray Al: New salicylic acid and isoflavone derivatives from Flemingia paniculata. I Nat Prod 2004, 67(3):402-6.

77. Das B, Tandon $V$, Saha N: Effects of phytochemicals of Flemingia vestita (Fabaceae) on glucose 6-phosphate dehydrogenase and enzymes of gluconeogenesis in a cestode (Raillietina echinobothrida). Comp Biochem Physiol C Toxicol Pharmacol 2004, I39(I-3): | $4 \mid-6$.

78. de Moura RM, Pereira PS, Januario AH, Franca Sde C, Dias DA: Antimicrobial screening and quantitative determination of benzoic acid derivative of Gomphrena celosioides by TLCdensitometry. Chem Pharm Bull (Tokyo) 2004, 52(I I):I342-4.

79. Herrera-Arellano A, Flores-Romero S, Chavez-Soto MA, Tortoriello I: Effectiveness and tolerability of a standardized extract from Hibiscus sabdariffa in patients with mild to moderate hypertension: a controlled and randomized clinical trial. Phytomedicine 2004, I I(5):375-82.

80. Akindahunsi AA, Olaleye MT: Toxicological investigation of aqueous-methanolic extract of the calyces of Hibiscus sabdariffa L. J Ethnopharmacol 2003, 89(I):161-4.

8I. Ali BH, Mousa HM, El-Mougy S: The effect of a water extract and anthocyanins of Hibiscus sabdariffa $L$ on paracetamolinduced hepatoxicity in rats. Phytother Res 2003, 17(1):56-9.

82. MacRae WD, Towers GH: Justicia pectoralis : a study of the basis for its use as a hallucinogenic snuff ingredient. J Ethnopharmacol 1984, I2(I):93-III.

83. Yadav NP, Dixit VK: Hepatoprotective activity of leaves of Kalanchoe pinnata Pers. J Ethnopharmacol 2003, 86(2-3):197-202.

84. Momo CE, Oben JE, Tazoo D, Dongo E: Antidiabetic and hypolipidaemic effects of a methanol/methylene-chloride extract of Laportea ovalifolia (Urticaceae), measured in rats with alloxan-induced diabetes. Ann Trop Med Parasitol 2006, I 00(I):69-74

85. Joyamma V, Rao SG, Hrishikeshavan HJ, Aroor AR, Kulkarni DR: Biochemical mechanisms and effects of Mimosa pudica (Linn) on experimental urolithiasis in rats. Indian J Exp Biol 1990, 28(3):237-40

86. Tongia A, Tongia SK, Dave M: Phytochemical determination and extraction of Momordica charantia fruit and its hypoglycemic potentiation of oral hypoglycemic drugs in diabetes mellitus (NIDDM). Indian J Physiol Pharmacol 2004, 48(2):24I-4.

87. Cummings E, Hundal HS, Wackerhage H, Hope M, Belle M, Adeghate $\mathrm{E}$, Singh J: Momordica charantia fruit juice stimulates glucose and amino acid uptakes in L6 myotubes. Mol Cell Biochem 2004, 26I(I-2):99-104.

88. Lemus I, Garcia R, Delvillar E, Knop G: Hypoglycaemic activity of four plants used in Chilean popular medicine. Phytother Res 1999, 13(2):91-4

89. Oku T, Yamada M, Nakamura M, Sadamori N, Nakamura S: Inhibitory effects of extractives from leaves of Morus alba on human and rat small intestinal disaccharidase activity. $\mathrm{Br}$ J Nutr 2006, 95(5):933-8.

90. Singab AN, El-Beshbishy HA, Yonekawa M, Nomura T, Fukai T: Hypoglycemic effect of Egyptian Morus alba root bark extract: effect on diabetes and lipid peroxidation of streptozotocin-induced diabetic rats. J Ethnopharmacol 2005, 100(3):333-8.

9I. Dhanabal SP, Sureshkumar M, Ramanathan M, Suresh B: Hypoglycemic effect of ethanolic extract of Musa sapientum on alloxan induced diabetes mellitus in rats and its relation with antioxidant potential. J Herb Pharmacother 2005, 5(2):7-19.

92. Ojewole JA, Adewunmi CO: Hypoglycemic effect of methanolic extract of Musa paradisiaca (Musaceae) green fruits in normal and diabetic mice. Methods Find Exp Clin Pharmacol 2003, 25(6):453-6.

93. Wolfram R, Budinsky A, Efthimiou Y, Stomatopoulos J, Oguogho A Sinzinger H: Daily prickly pear consumption improves platelet function. Prostaglandins Leukot Essent Fatty Acids 2003, 69(I):6I-6.

94. Villasenor IM, Lamadrid MR: Comparative anti-hyperglycemic potentials of medicinal plants. J Ethnopharmacol 2006, 104(I2):|29-3|

95. Singh S, Rehan HM, Majumdar DK: Effect of Ocimum sanctum fixed oil on blood pressure, blood clotting time and pentobarbitone-induced sleeping time. J Ethnopharmacol 200I, 78(23):139-43.

96. Hannan JM, Marenah L, Ali L, Rokeya B, Flatt PR, Abdel-Wahab YH: Ocimum sanctum leaf extracts stimulate insulin secretion from perfused pancreas, isolated islets and clonal pancreatic beta-cells. J Endocrinol 2006, I89(I):127-36.

97. Dhawan K, Dhawan S, Sharma A: Passiflora: a review update. J Ethnopharmacol 2004, 94: I-23.

98. Aziba PI, Adedeji A, Ekor M, Adeyemi O: Analgesic activity of Peperomia pellucida aerial parts in mice. Fitoterapia 200I, 72(I):57-58.

99. de Fatima Arrigoni-Blank M, Dmitrieva EG, Franzotti EM, Antoniolli $A R$, Andrade MR, Marchioro M: Anti-inflammatory and analgesic activity of Peperomia pellucida (L.) HBK (Piperaceae). J Ethnopharmacol 2004, 9I(2-3):2I5-8.

100. Khan MR, Omoloso AD: Antibacterial activity of Hygrophila stricta and Peperomia pellucida. Fitoterapia 2002, 73(3):25I-4. 
10I. Joshi A, Joshi K: Indigenous knowledge and uses of medicinal plants by local communities of the Kali Gandaki Watershed area, Nepal. J Ethnopharmacol 2000, 73(I-2):175-183.

102. de Fatima Arrigoni-Blank M, Dmitrieva EG, Franzotti EM, Antoniolli $A R$, Andrade MR, Marchioro M: Anti-inflammatory and analgesic activity of Peperomia pellucida (L.) HBK (Piperaceae). J Ethnopharmacol 2004, 9 I (2-3):2I5-8.

103. Aziba PI, Adedeji A, Ekor M, Adeyemi O: Analgesic activity of Peperomia pellucida aerial parts in mice. Fitoterapia 200I, 72(1):57-58

104. Raphael KR, Sabu MC, Kuttan R: Hypoglycemic effect of methanol extract of Phyllanthus amarus Schum \& Thonn on alloxan induced diabetes mellitus in rats and its relation with antioxidant potential. Indian J Exp Biol 2002, 40(8):905-9.

105. Rocha MJ, Fulgencio SF, Rabetti AC, Nicolau M, Poli A, Simoes CM, Ribeiro-do-Valle RM: Effects of hydroalcoholic extracts of Portulaca pilosa and Achyrocline satureioides on urinary sodium and potassium excretion. J Ethnopharmacol I994, 43(3): I79-83.

106. Chan K, Islam MW, Kamil M, Radhakrishnan R, Zakaria MNM, Habibullah $M$, Attas $A$ : The analgesic and anti-inflammatory effects of Portulaca oleracea L. subsp. sativa (Haw.) Celak. J Ethnopharmacol 2000, 73(3):445-45I.

107. Karimi G, Hosseinzadeh H, Ettehad N: Evaluation of the gastric antiulcerogenic effects of Portulaca oleracea $L$. extracts in mice. Phytother Res 2004, I 8(6):484-7.

108. Pari L, Latha M: Antihyperlipidemic effect of Scoparia dulcis (sweet broomweed) in streptozotocin diabetic rats. J Med Food 2006, 9(I): 102-7.

109. Guimaraes PR, Galvao AM, Batista CM, Azevedo GS, Oliveira RD, Lamounier RP, Freire N, Barros AM, Sakurai E, Oliveira JP, Vieira EC, Alvarez-Leite Jl: Eggplant (Solanum melongena) infusion has a modest and transitory effect on hypercholesterolemic subjects. Braz J Med Biol Res 2000, 33(9): 1027-36.

110. Botelho FV, Eneas LR, Cesar GC, Bizzotto CS, Tavares E, Oliveira FA, Gloria MB, Silvestre MP, Arantes RM, Alvarez-Leite Jl: Effects of eggplant (Solanum melongena) on the atherogenesis and oxidative stress in LDL receptor knock out mice (LDLR(-/-)). Food Chem Toxicol 2004, 42(8): 1259-67.

III. Maiti R, Jana D, Das UK, Ghosh D: Antidiabetic effect of aqueous extract of seed of Tamarindus indica in streptozotocininduced diabetic rats. J Ethnopharmacol 2004, 92(I):85-91.

1 12. Ruzaidi A, Amin I, Nawalyah AG, Hamid M, Faizul HA: The effect of Malaysian cocoa extract on glucose levels and lipid profiles in diabetic rats. J Ethnopharmacol 2005, 98( I-2):55-60.

1 3. Osakabe N, Yamagishi M, Natsume M, Yasuda A, Osawa T: Ingestion of proanthocyanidins derived from cacao inhibits diabetes-induced cataract formation in rats. Exp Biol Med (Maywood) 2004, 229(I):33-9.

I14. Alarcon-Aguilara FJ, Roman-Ramos R, Perez-Gutierrez S, AguilarContreras A, Contreras-Weber CC, Flores-Saenz JL: Study of the anti-hyperglycemic effect of plants used as antidiabetics. I Ethnopharmacol 1998, 61 (2): I0I-10.

I 15. Jagtap AG, Shirke SS, Phadke AS: Effect of polyherbal formulation on experimental models of inflammatory bowel diseases. J Ethnopharmacol 2004, 90(2-3): 195-204.

1 16. Habtemariam S: Extract of corn silk (stigma of Zea mays) inhibits the tumour necrosis factor- $\alpha$ - and bacterial lipopolysaccharide-induced cell adhesion and ICAM-I expression. Planta Med 1998, 64(4):3|4-3।8.

1 17. Brereton B: A history of modern Trinidad I 783-1962 Kingston, Jamaica: Heineman; 198I.

I 18. Buchler IR: Caymanian folk medicine: A problem in applied anthropology. Human Organisation 1964, 23(1):48-49.
Publish with Bio Med Central and every scientist can read your work free of charge

"BioMed Central will be the most significant development for disseminating the results of biomedical research in our lifetime. "

Sir Paul Nurse, Cancer Research UK

Your research papers will be:

- available free of charge to the entire biomedical community

- peer reviewed and published immediately upon acceptance

- cited in PubMed and archived on PubMed Central

- yours - you keep the copyright

Submit your manuscript here:

http://www.biomedcentral.com/info/publishing_adv.asp
BioMedcentral 